\title{
ДІАГНОСТУВАННЯ СТАНУ ГОТОВНОСТІ СТУДЕНТІВ ЕКОНОМІЧНОГО УНІВЕРСИТЕТУ ДО ТВОРЧОЇ САМОРЕАЛІЗАЦІЇ В МАЙБУТНІЙ ПРОФЕСІЙНІЙ ДІЯЛЬНОСТІ
}

Волосенко А. В. Діагностування стану готовності студентів економічного університету до творчої самореалізації в майбутній професійній діяльності.

У статті проаналізовано стан готовності студентів-майбутніх викладачів до творчої самореалізації, узагальнено думку студентів про заходи щодо підвищення ефективності їх творчої самореалізації в навчальному процесі університету.

Ключові слова: творча особистість, творча самореалізація особистості, готовність студентів до творчої самореалізації.

Волосенко А. В. Диагностирование состояния готовности студентов экономического университета к творческой самореализации в будущей профессиональной деятельности.

В статье проанализировано состояние готовности студентов-будущих преподавателей к творческой самореализации, обобщено мнение студентов о мерах по повышению эффективности их творческой самореализации в учебном процессе университета.

Ключевые слова: творческая личность, творческая самореализация личности, состояние готовности студентов к творческой самореализации.

Volosenko A. V. Diagnosing the level of students' readiness in the economic university to creative self-realization in their future professional activity.

The level of students - future lecturers' readiness to creative self-realization is analyzed. Students' ideas concerning means and ways of enhancing the effectiveness of their self-realization in the educational process are summarized.

Key words: creative personality, creative self-realization, students' readiness to creative selfrealization.

Реалізація творчих здібностей та якостей особистості є одним з основних чинників зростання й розвитку людства, тому навчання у вищій школі має бути спрямованим на формування у студентів творчого ставлення до майбутньої професійної діяльності, а також потреби реалізовувати свій особистісно-творчий потенціал.

Аналіз психолого-педагогічної літератури свідчить, що формування готовності майбутніх викладачів до творчої самореалізації під час студентського життя задає траєкторію розвитку професійних і особистісних виявів фахівця, формує впевненість у власних силах, віру в успішність майбутньої педагогічної діяльності, позитивне емоційне iii сприймання загалом та стимулює до подальшого саморозвитку й самоствердження особистості. Ось чому питання формування готовності майбутніх викладачів економіки до творчої самореалізації в непедагогічному університеті є нині актуальним та потребує проведення спеціальних досліджень.

Mета статmі: проаналізувати стан готовності студентів-майбутніх викладачів економіки до творчої самореалізації.

Проблема готовності особистості до будь-якого виду діяльності була і залишається однією з найбільш актуальних і широко висвітленою в психолого-педагогічній літературі. Метою констатувального експерименту стало визначення рівня готовності студентівмайбутніх викладачів економіки до творчої самореалізації. На початковому етапі ми дослідили психологічні особливості студентів-майбутніх економістів. Для цього нами було використано емпіричні методи дослідження, такі, як: спостереження, анкетування, інтерв'ю, бесіда, що, на нашу думку, є найбільш результативними методами педагогічного впливу. 
Відповідно до зазначеної мети проведено анкетування, у якому взяли участь 185 респондентів - студентів II і III курсів ДВНЗ «Київський національний економічний університет імені Вадима Гетьмана», що обрали додаткову спеціальність «викладач економіки».

Одне із завдань дослідження полягало у визначенні початкового рівня знань студентів про сутність поняття «творча самореалізації особистості» та суміжних понять із досліджуваної проблеми.

За результатами анкетування можна зробити висновок, що майже всі наведені терміни для студентів $\epsilon$ знайомими i зрозумілими. Труднощі виникають здебільшого у формулюванні понять «самоствердження», «саморегуляція» та «самоактуалізація». Базові поняття («творча особистість», «самореалізація», «творча самореалізація особистості»), на яких ми акцентуємо увагу, більшість опитаних знають і розуміють, однак значній частині складно сформулювати їх визначення. Зокрема, 82 \% опитаних зазначили, що знають і можуть визначити поняття «творча особистість» та «самореалізація». Що стосується «творчої самореалізації особистості», то лише 58 \% респондентів вказали на здатність дати визначення цьому поняттю, при цьому 37 \% студентів розуміють, але не можуть його тлумачити і 6 \% взагалі не розуміють його сутності. Отримані дані свідчать про недостатню поінформованість студентів стосовно процесу творчої самореалізації, самоактуалізації, самоствердження тощо.

Наступна авторська анкета, яка була запропонована студентам, сприяла вивченню рівня розуміння студентами основних понять досліджуваної проблеми, на яких ми акцентували свою увагу. Спершу респонденти повинні були дати своє визначення поняттям «творча особистість», «самореалізація особистості» та «творча самореалізація», що дало змогу більш чітко виявити, наскільки студенти розуміють їх сутність, та перевірити достовірність їх попередніх відповідей. Потім ми запропонували їм перелік визначень поняття «творча самореалізація» відомих науковців та авторське, серед яких вони мали вибрати те, яке, на їхню думку, найбільш повно відображає його.

Визначаючи поняття «творча особистість», погляди респондентів розділилися на дві групи. Одні характеризують пропоноване поняття з точки зору якісної оцінки творчої особистості. Зокрема, опитаними були наведені такі трактування: «людина, яка мислить нестандартно й оригінально, вільна у своїх думках і здатна до формування креативних ідей», «перебуває у постійному пошуку», «усебічно розвинена». Решта студентів визначають творчу особистість 3 огляду на можливість вияву особистісних здібностей у конкретній діяльності, а саме: «використовує свої творчі здібності», «застосовує творчий підхід у розв’язанні завдань», «втілює нові ідеї та фантазує», «створює нові власні продукти», «реалізовує себе в мистецтві».

Самореалізацію особистості студенти розглядають у кількох аспектах. Здебільшого вони стверджують, що це процес реалізації себе, своїх здібностей, потенціалу, талантів, внутрішніх ресурсів, умінь у професійній та особистісній сферах життя. Частина опитаних уважають, що самореалізація - це творення та формування власної особистості, пошук й усвідомлення свого місця й призначення в житті. Інша група респондентів визначає самореалізацію як кінцевий результат досягнення життєвих цілей та втілення мрій, при цьому особистість відчуває задоволення, радість та впевненість у собі.

Формулюючи визначення творчої самореалізації особистості, студенти повторюються у своїх твердженнях, додаючи лише, що творча самореалізація особистості передбачає реалізацію творчих здібностей, творче самовираження в галузях культури, освіти та мистецтва, досягнення успіху й поставлених цілей у творчій діяльності.

Серед наведеного переліку наявних визначень творчої самореалізації більшість студентів надали перевагу таким формулюванням: «цілеспрямований процес розвитку і творчого використання потенційних здібностей людини в особистісній, соціальній і професійній сферах життя, результатом якого $\epsilon$ предмети матеріального та нематеріального характеру» [4] та «процес здійснення особистістю своїх задумів задля 
досягнення визначеної мети в розв'язанні особистісно-значущих проблем, що дозволяють особистості максимально реалізувати свій творчий потенціал» [1].

Наступним завданням нашого дослідження було діагностування початкового рівня готовності студентів-майбутніх викладачів до творчої самореалізації. 3 цією метою нами запропоновано блоки питань анкети, за допомогою яких ми намагалися визначити рівень сформованості певних компонентів готовності, а саме: ціннісно-мотиваційного, особистісного, діяльнісно-творчого, когнітивного.

У динамічній і цілісній структурі готовності до творчої самореалізації основою $є$ ціннісно-мотиваційний компонент, що підтверджують дослідження науковців 3 розглядуваної проблеми (М. Морозова [3], А. Лісниченко [2], І. Тяллєва [4]). Будь-якій діяльності передує позитивне ставлення до неї, інтерес і мотивація. Тому нашу увагу було спрямовано насамперед на визначення основних мотивів, які вплинули на вибір студентами майбутнього професійного фаху. Система мотивів виконує регулятивну функцію в процесі підготовки майбутнього вчителя до творчої самореалізації та сприяє формуванню стійкого прагнення вчителя до професійного розвитку і зростання.

Більшість опитаних вказали на такий мотив вибору майбутньої професії, як інтерес до праці викладача (40\%), що свідчить про їх свідоме рішення та виражений інтерес до педагогічної діяльності. 3-поміж інших обставин, що зумовили вибір додаткового фаху, студенти визнали вплив друзів (25\%), любов до дітей (21\%), поради викладачів (15\%), батьків (9\%) та рекомендацію деканату (9\%).

Окрім зазначених мотивів вибору майбутньої професії, респондентами визначено й інші чинники, зокрема: важливість психолого-педагогічної підготовки для майбутнього професійного зростання, бажання бути корисним суспільству, загальний інтерес до педагогічних і психологічних дисциплін.

Отже, можна з упевненістю констатувати той факт, що більшість студентів професійно визначилися, що актуалізує ціннісне ставлення до навчальної діяльності в університеті.

Задля визначення рівня ціннісного аспекту зазначеного компонента готовності студентам було запропоновано обрати з наведеного переліку цінностей-цілей 5 найбільш значущих. Аналізуючи отримані дані, ми виходили з того, що саме життєві цілі та ціннісні орієнтації впливають на вибір важливих соціальних потреб.

Анкетування показало, що більша частина студентів мають чіткі життєві цілі та сформовану систему цінностей. У більшості з них домінує особистісний блок цінностей, однак варто зауважити, що поряд із такими загальноприйнятими для всіх цінностямицілями, як: «сім'я», «здоров'я», «кохання», «дружба», досить значне місце посідає цінність самореалізації та самовдосконалення.

Анкетування передбачало визначення студентами 5 найбільш значущих «цінностейзасобів». Отримані результати засвідчили, що для досягнення життєвих цілей студенти надали перевагу таким інструментальним цінностям, як: «інтелектуальність», «життєрадісність», «чесність», «незалежність», «працелюбність», що свідчить про їхню активну життєву позицію та налаштованість на досягнення професійної мети.

Ми запропонували їм надати відповідь на запитання щодо розвитку їх особистісних якостей. На нашу думку, саме такі якості, як допитливість, зосередженість, творчість, цілеспрямованість, самостійність, амбіційність, гнучке мислення, інтерес до нового, характеризують особистість, здатну до творчої самореалізації.

Більшість респондентів уважають, що володіють відповідними якісними характеристиками. У структурі їхньої особистості переважають такі якості: «допитливість», «цілеспрямованість», «самостійність» та «інтерес до нового». Однак, варто зауважити, що для формування особистісного компоненту готовності до творчої самореалізації важливими $є$ ще й такі якості особистості, як творчість, інтерес до нового, гнучкість мислення, що, як видно 3 результатів дослідження, $\epsilon$ недостатньо сформованими. 
Ми також поцікавились у студентів, чи вважають вони себе творчими особистостями. Значна частина (64\%) респондентів уважають себе творчими особистостями, $15 \%$ себе такими не вважають, однак деякі з них (8\%) - хотіли б бути творчими особистостями i $21 \%$ опитаних не змогли визначитися. Власний рівень творчого потенціалу переважна більшість студентів (62 \%) визначили як середній.

Питання щодо важливості формування готовності майбутніх викладачів економіки до творчої самореалізації як одного із завдань університету передбачало три варіанти відповіді, щодо яких студенти висловились так: уважаю суттєво важливим - 32 \%, уважаю необхідним - $49 \%$, не вважаю значущим - $9 \%$. Аналіз відповідей дозволив виявити, що більшість респондентів переконані в необхідності формування такої підготовки.

Важливою для нас була думка студентів про те, якими знаннями, вміннями та якостями вони хотіли б володіти для підвищення власного рівня готовності до творчої самореалізації в майбутній професійній діяльності. Зокрема, студентами названо такі чинники: знання (теоретичний навчальний матеріал, методи активізації, сучасні технології навчання, досвід інших викладачів, що успішно самореалізувалися у професійній діяльності, індивідуально-психологічні особливості учнів); уміння (використовувати набуті теоретичні знання на практиці, працювати 3 різними освітньо-віковими категоріями, управляти учнівським колективом); якості (комунікабельність, відповідальність, зосередженість, цілеспрямованість, упевненість, самостійність, креативність, творчість, стриманість).

Цікавими і корисними вважаємо висловлені студентами пропозиції щодо підвищення ефективності їхньої творчої самореалізації в навчальному процесі університету. 3-поміж запропонованих респондентами заходів, які доцільно б запровадити у навчальний процес, варто виокремити такі: створення умов для реалізації творчого потенціалу під час аудиторних занять; збільшення кількості годин із курсу психолого-педагогічних дисциплін, зокрема практичних занять; запровадження активних методів навчання, творчих завдань, орієнтованих на глибокі роздуми, вільне вираження власних ідей, максимальний вияв індивідуальності та здобуття практичних навичок викладання; проведення конференцій, дискусій, конкурсів; створення гуртків та проведення культурно-масових заходів.

Результати констатувального експерименту показують, що більшість студентів, обравши додаткову спеціальність «викладач економіки», зробили усвідомлений самостійний вибір, мають сформовану систему життєвих цінностей, достатньо повно розуміють сутність поняття «творча самореалізація», уважають проблему готовності особистості до творчої самореалізації істотною і важливою, рівень свого творчого потенціалу визначають як «середній».

Водночас, перспективу подальшого дослідження ми вбачаємо у проведенні цілеспрямованої роботи щодо формування у студентів готовності до творчої самореалізації у процесі майбутньої педагогічної діяльності.

\section{Література}

1. Андреев В. И. Педагогика творческого саморазвития: Инновационный курс / В. И. Андреев : В 2 кн. - Казань : Изд-во КГУ, 1996. - Кн. 1. - 568 с. 2. Лісниченко А. П. Підготовка майбутнього вчителя до творчої самореалізації в професійній діяльності [Текст] : дис. ... канд. пед. наук : 13.00.04 / Лісниченко Алла Павлівна ; Вінниц. держ. пед. ун-т ім. М. Коцюбинського. - Вінниця, 2011. 3. Морозова М. А. Формирование готовности студентов к самореализации в образовательном процессе вуза [текст] : дис. ... канд. пед. наук / М. А. Морозова. - Ульяновск, 2009. 4. Тяллєва І. О. Формування готовності вчителів іноземної мови до творчої самореалізації в професійній діяльності в системі післядипломної освіти : дис. ... канд. наук: 13.00.04 / Тяллєва Ірина Олексіївна, 2009. 